\title{
Trophic ecology of hawksbill turtles (Eretmochelys imbricata) in Golfo Dulce, Costa Rica: integrating esophageal lavage and stable isotope $\left(\delta^{13} \mathbf{C}, \delta^{15} \mathrm{~N}\right)$ analysis
}

\author{
Estefania Méndez-Salgado ${ }^{1}$, Didiher Chacón-Chaverri ${ }^{2}$, Luis G. Fonseca $^{2}$ \& Jeffrey A. Seminoff ${ }^{3}$ \\ ${ }^{1}$ Regional Postgraduate in Veterinary Sciences, National University of Costa Rica \\ Lagunilla de Heredia, Costa Rica \\ Ph.D. Program in Conservation Medicine, Facultad de Ciencias de la Vida \\ Universidad Andres Bello, Santiago, Chile \\ ${ }^{2}$ Latin American Sea Turtles Association, Playa Blanca, Puntarenas, Costa Rica \\ ${ }^{3}$ NOAA-National Marine Fisheries Service, Southwest Fisheries Science Centre \\ La Jolla, California USA \\ Corresponding author: Estefania Méndez-Salgado (esteamofis@yahoo.com)
}

\begin{abstract}
Hawksbill turtles (Eretmochelys imbricata), considered Critically Endangered, have several small populations in the Eastern Pacific (EP). Knowledge about their diet and habitat use can aid in developing conservation strategies and promoting population recovery in the region. Although considered a spongivore in the Caribbean, data from the EP region indicate that hawksbills consume a wide array of prey species, including angiosperms. We used two approaches to study the diet of hawksbills at Golfo Dulce, Costa Rica: oesophageal lavage and stable isotope $\left(\delta^{13} \mathrm{C}, \delta^{15} \mathrm{~N}\right)$ analysis of bulk skin tissue and blood plasma. Lavage samples collected from 41 turtles revealed macroalgae as the predominant diet item $(\mathrm{Rw}=20.22)$, followed by sea snails and excavating worms. Stable isotope values for blood plasma from 44 turtles ranged from $-23.0 \%$ to $-15.7 \%$ for $\delta^{13} \mathrm{C}$ and $6.9 \%$ to $10.4 \%$ for $\delta^{15} \mathrm{~N}$, whereas values for skin tissue were $-20.4 \%$ to $-13.9 \%$ and $9.3 \%$ to $11.0 \%$ o for $\delta^{13} \mathrm{C}$ and $\delta^{15} \mathrm{~N}$, respectively. We compared these isotope values with those of five potential prey groups (sponge, sea snail, excavating worm, mangrove, macroalgae) using a multisource stable isotope mixing model analysis in R (SIAR). Our results indicated that multiple prey resources are important for hawksbills in Golfo Dulce, where sea snails, sponges and excavating worms contributed up to $63 \%$ of the assimilated diet per individual, and mangrove and macroalgae up to 50\%. These data show that hawksbills in Golfo Dulce, and perhaps the wider EP region, are omnivorous, underscoring the importance for considering alternative habitats, aside of coral reefs, for its management and restoration.
\end{abstract}

Keywords: Eretmochelys imbricata; marine turtles; diet; resource requirements; eastern Pacific

\section{INTRODUCTION}

Within coastal anthropogenically impacted habitats understanding the biology of threatened species is fundamental for their conservation (Wallace et al., 2010, 2011). Knowledge about the species' feeding behaviour, diet and trophic ecology can be useful for identifying the most important resources within foraging areas and can help pinpoint priority sites for habitat protection (Blumenthal et al., 2009; Gaos et al., 2012b; Seminoff et al., 2012; Revuelta et al., 2015). Sea turtles represent a valuable and enigmatic taxonomic group, for which this information is appropriate for conservation practices (Hamann et al., 2010; Rees et al., 2016).

A variety of methods have been developed to study sea turtle feeding behavior and diet composition, including direct observation, esophageal lavage, faecal examination and stable isotopes analysis (SIA) (Forbes, 1999; Gaos et al., 2011; Jones \& Seminoff, 2013). Each of these methods has its pros and cons: for example, esophageal lavage is a relatively simple, low-cost technique that provides information about recently ingested items, but the recovered diet items are often biased toward softer and smaller items, many of which are too small to identify to species. Lavage may also

Corresponding editor: Joanna Alfaro 
reveal items that are consumed but not assimilated, which thus hinders the interpretation of the most important foods for nutrition (Forbes, 1999; Seminoff et al., 2002; Lemons et al., 2011). In contrast, direct observation may be a less invasive way to observe diet intake by sea turtles in the wild, but this approach is often logistically difficult for cryptic species that respond negatively to human observers in their surroundings. Furthermore, this technique can be timeconsuming and susceptible to inconsistent results due to environmental variability (e.g., water visibility, Blumenthal et al., 2009; Mancini et al., 2015).

A relatively new approach for determining the diet and trophic ecology of consumer species, such as sea turtles, is bulk tissue SIA (Godley et al., 1998). This technique yields information about the trophic status and dietary history of an individual via collection of small tissue samples and analysis of their stable isotope compositions. This is based on the fact that the isotopic composition of a consumer's body tissues is derived from its prey sources and the ecosystem within which it lives (Reich et al., 2008; Jones \& Seminoff, 2013; Carpentier et al., 2015). Stable nitrogen isotope values $\left(\delta^{15} \mathrm{~N}\right)$ are used for estimating the trophic position of a consumer within a food web due to the step-wise enrichment of $\delta^{15} \mathrm{~N}$ with each trophic step (Jones \& Seminoff, 2013; Carpentier et al., 2015), whereas stable carbon isotope $\left(\delta^{13} \mathrm{C}\right)$ values of consumer tissues are generally used to determine the source of nutrients, with a continuum of progresive $\delta^{13} \mathrm{C}$ depletion in tissue of animals as they forage farther from the coast (Gannes et al., 1998; Jones \& Seminoff, 2013). In omnivores or herbivores, $\delta^{13} \mathrm{C}$ values in tissue may also be influenced by the photosynthetic reactions and glucose synthesis of plant species, as well as the carbon sources for these consumed foods (Hobbie \& Werner, 2004). For example, in coastal estuarine habitats, mangroves (e.g., Rhizophora mangle), which are marine angiosperms that derive carbon from terrestrial-based systems, will have substantially depleted $\delta^{13} \mathrm{C}$ values relative to seagrass and, to a lesser extent, marine macroalgae located only a few meters away (Lepoint et al., 2004). As a result, SIA is complementary to other techniques such as esophageal lavage, and their concurrent application can provide a more holistic perspective about what prey items are most important for nutrient assimilation in wildlife species (Williams et al., 2014; Espinoza et al., 2015).

The hawksbill turtle (Eretmochelys imbricata) is listed as Critically Endangered on the International Union for Conservation of Nature (IUCN) Red List (IUCN, 2017) because of population declines around the world, due largely to the commercialization of its shell and eggs (UICN, 2016). In the Caribbean, the species is considered spongivorous (Meylan, 1988; León \& Bjorndal, 2002; Parker et al., 2009; Bell, 2012; Wood et al., 2017); however, the feeding ecology of hawksbills in the eastern Pacific (EP) is unclear, and may vary spatially, depending on the habitat occupied. Seminoff et al. (2003) reported that the stomachs of two dead hawksbills in the Gulf of California, at the extreme northern edge of their range, consisted largely of the sponge Haliclona sp., whereas Carrión et al. (2013) described diet for 13 individuals along the Nicoya Peninsula, Costa Rica, reporting that their diet consisted of the sponge Geodia sp. and the ascidian Rhopalaea birkelandi. Considering the small sample sizes of previous studies, additional information is needed to better understand hawksbill foraging ecology in the EP region.

One area that hosts relatively large numbers of hawksbills, but at which diet has not yet been studied, is Golfo Dulce, a tropical estuarine fjord along the Pacific coast of Costa Rica (Fig. 1). Here, we examined the diet and trophic status of hawksbills using multiple approaches. We used esophageal lavage to evaluate ingested diet items, and we applied stable-carbon $\left(\delta^{13} \mathrm{C}\right)$ and -nitrogen $\left(\delta^{15} \mathrm{~N}\right)$ isotope analysis of bulk skin tissue and blood plasma to infer the most important assimilated foods for hawksbills. Our stable isotope data were also used to infer individual fidelity to this ecosystem by analyzing the information obtained from recaptured individuals and inspecting for aberrant isotopic values that were not indicative of the local stable isotope regime. These findings will contribute greater information to support the conservation strategies for this protected coastal ecosystem and its resources, indirectly ensuring the conservation of this emblematic species. Our data will also serve as a baseline for which to compare with future studies of hawksbill foraging ecology in Golfo Dulce and other areas within the EP.

\section{MATERIALS AND METHODS}

\section{Study area}

We studied hawksbill turtles along the coast of Playa Blanca in the western portion of Golfo Dulce, Costa Rica (N08³8'0.384” W83²6’0.202”; Fig. 1). This region is characterized by the presence of seagrasses, macroalgae, and mangroves with small patches of degraded coral reefs (Cortés, 1991; León \& Vargas, 1998; Morales, 2010; Samper et al., 2014). Golfo Dulce is a broad, fjord-like embayment approximately $50 \mathrm{~km}$ long and $10-15 \mathrm{~km}$ wide. A sill area $20 \mathrm{~km}$ from the bay's entrance separates an inner, flat bottom basin with depths up to $215 \mathrm{~m}$ from a shallow outer basin. Annually, the air temperature typically varies from 


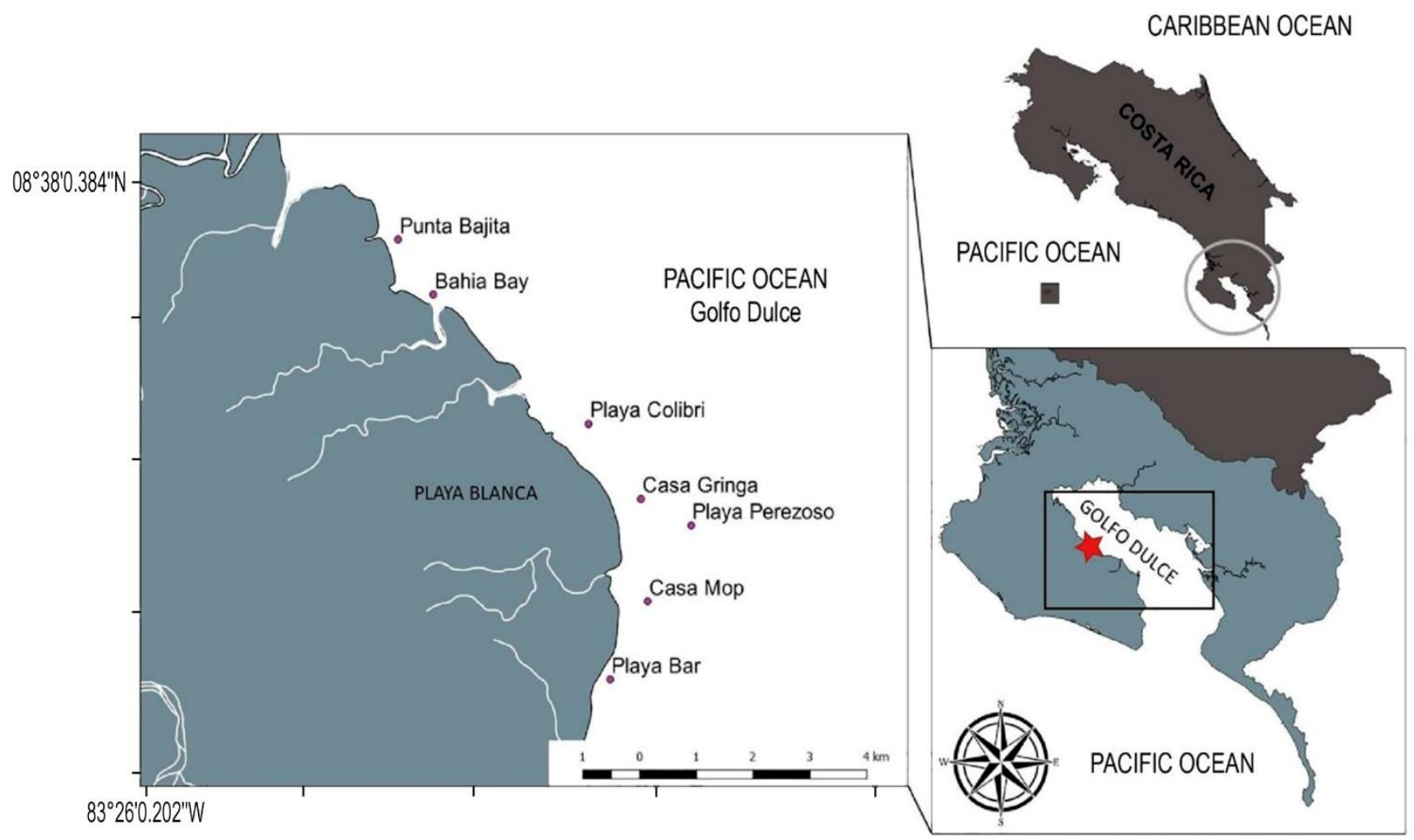

Figure 1. Sampling areas of hawksbill turtles (Eretmochelys imbricata) foraging in Golfo Dulce, Costa Rica.

$23^{\circ} \mathrm{C}$ to $33^{\circ} \mathrm{C}$, and rarely gets below $21^{\circ} \mathrm{C}$ or above $35^{\circ} \mathrm{C}$. The hot season lasts from January to April, with an average daily maximum air temperature above $32^{\circ} \mathrm{C}$. The cool season occurs from August to December, with an average daily maximum air temperature below $29^{\circ} \mathrm{C}$ (Svendsen et al., 2006).

\section{Turtle capture}

Seven hawksbill capture sites were established (Fig. 1), which cover the variety of habitat types within Playa Blanca (Table 1). Two entanglement nets (mesh size 50 $\mathrm{cm}$ ), one measuring $100 \times 8 \mathrm{~m}$ and the other $80 \times 8 \mathrm{~m}$, were joined together and used for hawksbill captures. The attached nets were set for a minimum of six hours, starting at 08:00, and were constantly monitored during the entire soak time. Net orientation and distance from shore $(100$ to $500 \mathrm{~m}$ ) varied depending on the tides and precipitation (Chacón et al., 2015). Once the nets were positioned, they were georeferenced with a global positioning system (Model 62S, Garmin $\left.{ }^{\circledR}\right)$. We calculated catch per unit effort (CPUE) as the total number of hawksbill turtles caught in each sampling event divided by the number of capture effort units, defined as the deployment of $180 \mathrm{~m}$ of net for $6 \mathrm{~h}$ (Chacón et al., 2015).
Upon capture, turtles were transported to the shore where they were processed (Chacón et al., 2015). We measured curved carapace length (CCL) from the nuchal notch to the posterior-most tip of the carapace. We conducted each measurement three times with a flexible tape measure and recorded the mean of these three measurements $( \pm 1.0 \mathrm{~mm})$ to reduce error (Labrada, 2011; Carrión et al., 2013; Chacón et al., 2015). Turtles were classified as putative adults if their $\mathrm{CCL} \geq 62.2 \mathrm{~cm}$ (Gaos et al., 2017). Each turtle was tagged with an Inconel ${ }^{\circledR}$ flipper tag (Style 681, National Band and Tag Co., Newport, KY, USA) in the second axillary scale of each front flipper (Chacón et al., 2015) if it was not previously tagged. All recaptured turtles were re-measured, but tissue samples were collected only from turtles recaptured $\geq 1$ month after the previous capture (Seminoff et al., 2007). All personnel involved in the handling process used latex gloves as per biosecurity regulations and all tissue collection and flipper tagging sites were disinfected with alcohol (Forbes, 1999; Chacón et al., 2015). After measurement and sampling, all turtles were released at the site of initial capture (Labrada, 2011; Chacón et al., 2015), usually within $30 \mathrm{~min}$. 
Table 1. Description of areas where hawksbill turtle Eretmochelys imbricata sampling took place between March and August 2015.

\begin{tabular}{|c|c|c|}
\hline Location & Coordinates (CR-05) & Description \\
\hline Playa Bar & $08^{\circ} 38^{\prime} 0.87^{\prime \prime} \mathrm{N} \quad 83^{\circ} 26^{\prime} 0.325^{\prime \prime} \mathrm{W}$ & $\begin{array}{l}\text { Predominantly rocky and sandy bottom, with patches of seagrass. } \\
\text { Coastal vegetation mainly of palms with patches of mangrove. }\end{array}$ \\
\hline Casa Mop & $08^{\circ} 38^{\prime} 0.280^{\prime \prime} \mathrm{N} \quad 83^{\circ} 26^{\prime} 0.276^{\prime \prime} \mathrm{W}$ & $\begin{array}{l}\text { A substrate of rocky, muddy, and sandy patches, with seagrass and } \\
\text { presence of degraded coral formations. The coast of mixed } \\
\text { vegetation with mangrove and palm. River mouth. }\end{array}$ \\
\hline Playa Perezoso & $08^{\circ} 38^{\prime} 0.504^{\prime \prime} \mathrm{N} 83^{\circ} 25^{\prime} 0.513^{\prime \prime} \mathrm{W}$ & $\begin{array}{l}\text { Mixed rocky, sandy, and muddy substrate. Coast with mangroves } \\
\text { and palms. }\end{array}$ \\
\hline Casa Gringa & $08^{\circ} 39^{\prime} 0.830^{\prime \prime} \mathrm{N} 83^{\circ} 25^{\prime} 0.537^{\prime \prime} \mathrm{W}$ & $\begin{array}{l}\text { Muddy and sandy bottom, with seagrass. Coast with mangrove and } \\
\text { palms. }\end{array}$ \\
\hline Playa Colibrí & $08^{\circ} 39^{\prime} 0.352^{\prime \prime} \mathrm{N} 83^{\circ} 25^{\prime} 0.548^{\prime \prime} \mathrm{W}$ & $\begin{array}{l}\text { Muddy and sandy bottom, with seagrass. Coast mainly of palms. } \\
\text { River mouth. }\end{array}$ \\
\hline Bahía Bay & $08^{\circ} 40^{\prime} 0.999^{\prime \prime} \mathrm{N} 83^{\circ} 26^{\prime} 0.301^{\prime \prime} \mathrm{W}$ & $\begin{array}{l}\text { Muddy and sandy soil with seagrass. Coastal mangrove vegetation. } \\
\text { River mouth. }\end{array}$ \\
\hline Punta Bajita & $08^{\circ} 40^{\prime} 0.324^{\prime \prime} \mathrm{N} 83^{\circ} 26^{\prime} 0.462^{\prime \prime} \mathrm{W}$ & $\begin{array}{l}\text { Muddy and sandy bottom with seagrass. Coast with mangroves. } \\
\text { River mouth. }\end{array}$ \\
\hline
\end{tabular}

\section{Esophageal lavage}

We conducted oesophageal lavage on each captured turtle following previously established protocols (Forbes, 1999; Stokes \& Epperly, 2008; Bell, 2012; Carrión et al., 2013). Briefly, each turtle was placed on its plastron at a $45^{\circ}$ angle and a tube was inserted into the turtle's mouth no deeper than the intersection between the neck and anterior plastron. The diameter of the wash tube ranged from 0.5 to $1 \mathrm{~cm}$ outside diameter and was changed according to the size of each turtle so as to diminish the possibility of injuring it's oesophagus (Bell, 2012; Carrión et al., 2013). For each turtle, lavage efforts lasted $5 \mathrm{~min}$ or less and were conducted with three litres of clean seawater collected from the same area where the turtle was captured. Lavage samples were preserved in a saturated salt $(\mathrm{NaCl})$ solution and refrigerated until analysis. After transfer to the laboratory of the Regional Institute of Toxic Substances Studies of the National University of Costa Rica (UNA, for its acronym in Spanish), the net weight of each sample was determined and all recovered diet items were examined by microscope and identified to the lowest taxonomic unit (Forbes, 1999; Stokes \& Epperly, 2008; Carrión et al., 2013).

\section{Skin tissue collection and preparation}

We collected epidermis (i.e., skin) tissue (stratum corneum) from the dorsal surface of the neck of each captured turtle using a razor blade. We were careful to collect only epidermal tissue, avoiding the connective tissue layer. Skin samples were preserved in saturated salt solution and placed on ice for transport to the laboratory, where they were stored at $-20^{\circ} \mathrm{C}$ until preparation and analysis (McClellan et al., 2010; Reich
\& Seminoff, 2010; Lemons et al., 2011). Prior to SIA, skin samples were thawed, rinsed with distilled water, frozen at $-80^{\circ} \mathrm{C}$ and lyophilized for $24 \mathrm{~h}$ in the Laboratory of Bacteriology at UNA. Dried samples were then stored in labelled vials until preparation for SIA.

\section{Blood sample collection and preparation}

Blood samples were obtained via the dorsal cervical sinus (Owens \& Ruiz, 1980). Puncture sites were cleansed with alcohol and betadine and a 23 or 25 gauge needle was used to obtain the sample (Strik et al., 2007). From each individual, $4 \mathrm{~mL}$ of blood were collected, stored in Vacuette ${ }^{\circledR}$ lithium heparin tubes, and centrifuged for five minutes to separate the plasma from cellular blood constituents (Owens \& Ruiz, 1980; Seminoff et al., 2006; Lemons et al., 2012). Plasma was then transferred to labelled tubes and stored in liquid nitrogen until preparation for SIA. Prior to analysis, each plasma sample was lyophilized for $24 \mathrm{~h}$ then stored in a microtube at room temperature until $\delta^{13} \mathrm{C}$ and $\delta^{15} \mathrm{~N}$ analyses (Reich \& Seminoff, 2010; Seminoff et al., 2012).

\section{Prey sample collection and preparation}

Tissue and whole bodies of putative prey species were collected during opportunistic SCUBA efforts along the coast of Playa Blanca, mostly gathered from rockybottom areas such as Playa Bar, Casa Mop and Playa Perezoso (Fig. 1). We collected three 'indicator' species in as many areas as possible to determine $\delta^{13} \mathrm{C}$ and $\delta^{15} \mathrm{~N}$ values for putative hawksbill prey within the study area. These included the sponge (Mycale sp.), an excavating worm (Amphicteis sp.) and a snail (Cerithium sp.). These species were abundant within Golfo Dulce and were 
considered possible dietary items based on previous reports (Gaos et al., 2011, 2012b; Carrión et al., 2013). In total, we collected eight snail samples, six worm samples, and four sponge samples. Diet samples were preserved in saturated salt solution and stored at $-20^{\circ} \mathrm{C}$ until preparation and $\delta^{13} \mathrm{C}$ and $\delta^{15} \mathrm{~N}$ analyses. We were unable to collect mangrove (Rhizophora mangle) and macroalgae within our study area due to logistic constraints; we therefore used values published in the literature for Gulf of Chiriquí, Panamá (Viana et al., 2015), which is relatively close to Golfo Dulce and within the same marine isotopic regime (Table 2; Seminoff et al., 2012, unpubl. data).

\section{Stable isotope measurement}

Prepared samples were sent to the Department of Geosciences Stable Isotope Laboratory at University of Florida, Gainesville, Florida USA, where they were loaded into sterilized tin capsules and analysed by a continuous-flow isotope-ratio mass spectrometer (Lemons et al., 2011). We used a Costech ECS 4010 elemental combustion system interfaced via a ConFlo III device (Finnigan MAT, Bremen, Germany) to a Deltaplus gas isotope-ratio mass spectrometer (Finnigan MAT, Bremen, Germany) (Lemons et al., 2011). Sample SI ratios relative to the isotope standard are expressed in the following conventional delta $(\delta)$ notation in parts per thousand (\%): $\delta=$ $\left(\left[\frac{\mathrm{R}_{\text {sample }}}{\mathrm{R}_{\text {standard }}}\right]-1\right) \times 1000$, where $\mathrm{R}_{\text {sample }}$ and $\mathrm{R}_{\text {standard }}$ are

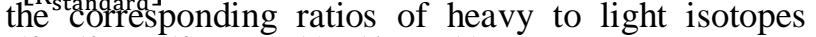
$\left({ }^{13} \mathrm{C} /{ }^{12} \mathrm{C}: \delta^{13} \mathrm{C}\right.$ and ${ }^{15} \mathrm{~N} /{ }^{14} \mathrm{~N}$ : $\left.\delta^{15} \mathrm{~N}\right)$ in the sample and standard, respectively (Lemons et al., 2011). $\mathrm{R}_{\text {standard }}$ for ${ }^{13} \mathrm{C}$ was Baker Acetanilide $\left(\mathrm{C}_{8} \mathrm{H}_{9} \mathrm{NO} ; \delta^{13} \mathrm{C}=\right.$ $-10.4 \%$ ) calibrated monthly against the Peedee Belemnite (PDB) limestone formation international standard; $\mathrm{R}_{\text {standard }}$ for ${ }^{15} \mathrm{~N}$ was IAEA N1 Ammonium Sulfate $\left(\left(\mathrm{NH}_{4}\right)_{2} \mathrm{SO}_{4} ; \delta^{15} \mathrm{~N}=+0.4 \%\right)$ calibrated against atmospheric $\mathrm{N}_{2}$ and USGS Nitrogen standards. All analytical runs included samples of standard materials inserted every 6 to 7 samples to calibrate the system and compensate for any drift over time. Replicate assays of standard materials indicated measurement errors of $0.05 \%$ and $0.095 \%$ for carbon and nitrogen, respectively. In addition to SI ratios, we measured $\% \mathrm{C}$ and $\% \mathrm{~N}$ for each diet and tissue sample (Lemons et al., 2011). Samples were combusted in pure oxygen in the elemental analyser. Resultant $\mathrm{CO}_{2}$ and $\mathrm{N}_{2}$ gasses were passed through a series of thermal conductivity detectors and element traps to determine percent compositions. Acetanilide standards $(10.36 \% \mathrm{~N}, 71.09 \% \mathrm{C})$ were used for calibration (Lemons et al., 2011).

\section{Statistical analysis}

We determined the percent volume (\% VO) for each of the items recovered in oesophageal lavages, we determined the percent volume for each one $(\% \mathrm{VO})$ where $\% \mathrm{VO}=\frac{\text { item weight in diet }}{\text { total sample weight }} \times 100$. Any element with a $\% \mathrm{VO}$ greater than $5 \%$ in at least one sample was considered to be major diet item and not incidentally consumed (Arthur \& Balazs, 2008; Carrión et al., 2013). We calculated the frequency of occurrence $(\% \mathrm{FO})$ for all diet constituents (Mohan \& Sankara, 1988; Carrión et al., 2013), where:

$$
\% \mathrm{FO}=\frac{\text { number of samples in which the item was observed }}{\text { total number of samples }} \times 100
$$

The results from these two calculations were combined to create a weighted index (Rw) that allowed us to estimate the order of importance of each element for the suite of items consumed (Mohan \& Sankaran, 1988; Carrión et al., 2013). This index was plotted as a function of the angle $(\theta)$, allowing us to interpret the importance of each element based on the consistency of $\% \mathrm{VO}$ and \%FO (Mohan \& Sankaran, 1988).

$$
\begin{gathered}
\mathrm{Rw}=\frac{\mathrm{Q}\left(\mathrm{V}^{2}+\mathrm{FO}^{2}\right)^{\frac{1}{2}}}{\sum \mathrm{Q}\left(\mathrm{V}^{2}+\mathrm{FO}^{2}\right)} \times 100, \text { where } \\
\mathrm{Q}=\frac{45-|\theta-45|}{45}, \text { where } \theta=\tan ^{-1} \frac{\mathrm{FO}}{\mathrm{V}}
\end{gathered}
$$

Rw values varied between 0 and 100 , where the elements closer to 100 represented the most important dietary components, whereas those items closer to 0 were of lesser dietary importance (Carrión et al., 2013).

We used the stable isotope mixing model Stable Isotope Analysis in R (SIAR) to establish the possible dietary constituents and their contributions to hawksbill diet. The model was run using the diet-tissue discrimination factors $\left(\Delta_{\mathrm{dt}}\right)$ from small juvenile loggerhead turtles (Caretta caretta; Reich et al., 2008), as this is the most closely-related and ecologically-similar sea turtle species to hawkbills for which $\Delta_{\mathrm{dt}}$ values are available. For skin, $\Delta_{\mathrm{dt}}{ }^{13} \mathrm{C}=2.62 \pm 0.34$ and $\Delta_{\mathrm{dt}}{ }^{15} \mathrm{~N}=$ $1.65 \pm 0.12$, whereas for plasma, $\Delta_{\mathrm{dt}}{ }^{13} \mathrm{C}=0.29 \pm 0.20$ and $\Delta_{\mathrm{dt}}{ }^{15} \mathrm{~N}=0.32 \pm 0.09$. Monthly distributions of prey contributions were generated with SIAR (Lemons et al., 2011) to determine if prey contributions changed during the study duration.

\section{RESULTS}

We conducted 42 field capture efforts and successfully captured at least one hawksbill turtle during 36 of these campaigns. There were 51 captures of 41 individuals, with four turtles captured two times, and three turtles captured three times. The mean CPUE during our study was 0.2 captured turtles per hour of effort, although the capture rate varied among the monitoring sites (Fig. 3). A total of 25 turtles were classified as putative adults and 16 as juveniles. The average CCL of putative adults 
Table 2. Stable isotope values for the putative hawksbill turtles Eretmochelys imbricata prey, which were used in mixing model analyses. All values are shown with standard deviation (SD).

\begin{tabular}{lrrr}
\hline Element & $\mathrm{n}$ & $\mathrm{Mean} \delta^{15} \mathrm{~N} \pm \mathrm{SD}(\% \mathbf{0})$ & $\mathrm{Mean} \delta^{13} \mathrm{C} \pm \mathrm{SD}(\%)$ \\
\hline Cerithium sp. & 5 & $5.381 \pm 1.173$ & $-10.046 \pm 1.425$ \\
Amphicteis sp. & 3 & $2.966 \pm 0.265$ & $-15.224 \pm 0.615$ \\
Mycale sp. & 4 & $6.079 \pm 1.727$ & $-9.319 \pm 5.172$ \\
Mangrove (R. mangle, P. rhizophorae and A. germinans) (Viana et al., 2015) & - & $3.700 \pm 1.000$ & $-29.200 \pm 1.200$ \\
Macroalgae (Viana et al., 2015) & - & $3.300 \pm 1.200$ & $-30.700 \pm 1.200$ \\
\hline
\end{tabular}

Table 3. Summary of hawksbill turtles Eretmochelys imbricata captured in their feeding area in Golfo Dulce, Costa Rica, between March and August 2015. CCL: curved carapace length. SD: standard deviation.

\begin{tabular}{lcclcc}
\hline & \multicolumn{2}{c}{ Number of captures } & & \multicolumn{2}{c}{ Size $(\mathrm{cm})$} \\
\cline { 2 - 3 } \cline { 5 - 6 } Month & Juveniles & Putative adults & & CCL \pm SD & Range \\
\hline March & 1 & 9 & & $70.7 \pm 6$ & $59.8-81.0$ \\
April & 0 & 3 & & $69.3 \pm 4.4$ & $63.0-72.7$ \\
May & 5 & 5 & & $62.1 \pm 10.6$ & $47.1-79.4$ \\
June & 3 & 3 & & $65.8 \pm 8.2$ & $52.1-77.1$ \\
July & 6 & 6 & & $60.6 \pm 11.1$ & $39.5-77.7$ \\
\hline
\end{tabular}

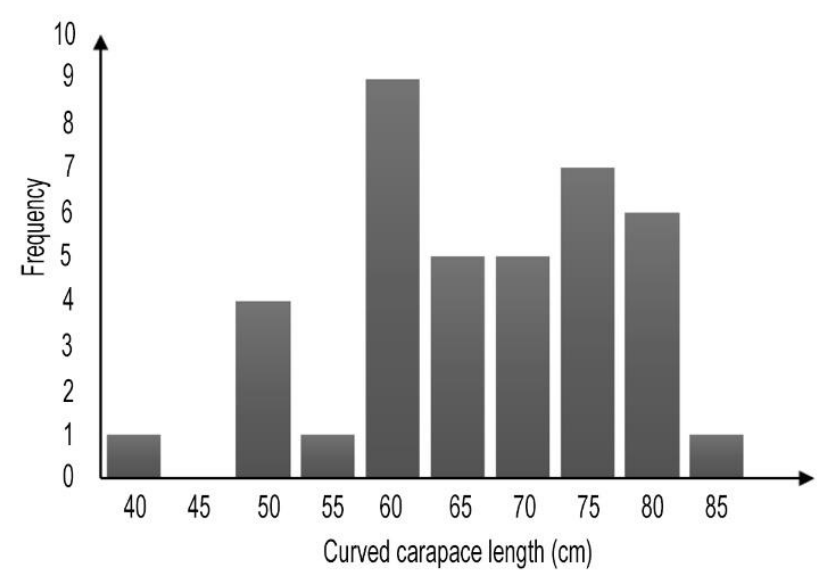

Figure 2. Summary of curved carapace lengths of hawksbill turtles Eretmochelys imbricata $(\mathrm{n}=40)$ captured near Playa Blanca in Golfo Dulce, Costa Rica.

was $70.3 \pm 4.9 \mathrm{~cm}$ (range $=62.1$ to $81 \mathrm{~cm})$, whereas that for juveniles was $53.2 \pm 5.68 \mathrm{~cm}$ (range $=39.5$ to 59.77 cm; Table 3, Fig. 2).

\section{Oesophageal lavage}

Esophageal lavage was performed on all 41 captured hawksbills with a mean wet weight per lavage sample of $0.05 \pm 0.07 \mathrm{~g}$ (range $=0.0005$ to $0.35 \mathrm{~g}$ ). From one to seven dietary elements were obtained per sample, and a total of 12 species were distinguished (Table 4).

The predominant diet items for hawksbills examined during this study were the macroalgae Bostrychia moriziana $(\% \mathrm{VO}=44.73 \pm 33.99, \% \mathrm{FO}=64)$ and
Laurencia obtusa $(\% \mathrm{VO}=30.86 \pm 27.13, \% \mathrm{FO}=62)$, and the mollusk Cerithium sp. $(\% \mathrm{VO}=29.37 \pm 23.71$, $\% \mathrm{FO}=50)($ Fig. 3).

According to the $\mathrm{Rw}$ values, the order of importance of diet elements for hawksbills was B. moriziana $>L$. obtusa $>$ Cerithium sp. $>$ Amphicteis sp. $>$ Halophila sp. $>$ Mycale sp. $>$ R. mangle > Coronatae > Geodia sp. $>$ Copepoda > Halodule sp. > Halimeda discoidea (Fig. 4). B. moriziana was the diet element of greatest importance with a high $\mathrm{Rw}$ value (20.22). The angles of consumed items that are close to $45^{\circ}$ are considered as abundant and frequent in consumption, and, based on this approach, the annelid Amphicteis sp. and the sponge Mycale sp. were both frequent and abundant in hawksbill diet as indicated by their angles (41.09 and $48.95^{\circ}$, respectively).

\section{Stable carbon and nitrogen isotope values}

Elemental concentrations $(\% \mathrm{C}, \% \mathrm{~N})$ and isotopic values $\left(\delta^{13} \mathrm{C}, \delta^{15} \mathrm{~N}\right)$ for skin tissue and blood plasma collected from hawksbills from March to August 2015 are shown in Table 5 . The $\% \mathrm{C}$ range for plasma was 36.0 to $45.6 \%$, whereas for $\% \mathrm{~N}$ ranged from 9.2 to $11.7 \%$. The $\% \mathrm{C}$ and $\% \mathrm{~N}$ ranges in the skin were 34.7 to $44.5 \%$ and of 12.4 to $15.7 \%$, respectively. Plasma $\delta^{13} \mathrm{C}$ values ranged from -23.0 to $-15.7 \%$ (mean $=-18.2$ $\pm 1.7 \%$ ) and for $\delta^{15} \mathrm{~N}$ from 6.9 to $10.4 \%$ (mean $=7.8 \pm$ $0.5 \%$ ). For skin, $\delta^{13} \mathrm{C}$ ranged from -20.4 to $-13.9 \%$ (mean $=-15.9 \pm 1.5 \%$ ) and $\delta^{15} \mathrm{~N}$ ranged from 9.3 to $11.0 \%$ o $($ mean $=10.0 \pm 0.6 \%$ o). 
Table 4. Items recovered in the esophageal lavage samples of hawksbill turtles Eretmochelys imbricata caught in Golfo Dulce. Values are presented as mean volume percentage (\%VO) and standard deviation (SD), frequency of occurrence $(\% \mathrm{FO})$, angle, angle deviation measure $=45^{\circ}(\mathrm{Q})$ and the resulting weighted index $(\mathrm{Rw})$.

\begin{tabular}{|c|c|c|c|c|c|}
\hline Species & Mean $\%$ VO (n) \pm SD & $\% \mathrm{FO}(\mathrm{n})$ & Angle & $\mathrm{Q}$ & $\mathrm{Rw}$ \\
\hline \multicolumn{6}{|l|}{ Macroalgae } \\
\hline \multicolumn{6}{|l|}{ Phylum Chlorophyta } \\
\hline Halimeda discoidea & $13.28(\mathrm{n}=1) \pm 0.00$ & $2(\mathrm{n}=1)$ & 8.56 & 0.19 & 0.85 \\
\hline \multicolumn{6}{|l|}{ Phylum Rhodophyta } \\
\hline Laurencia obtusa & $30.86(\mathrm{n}=31) \pm 27.13$ & $62(\mathrm{n}=31)$ & 63.54 & 0.59 & 13.58 \\
\hline Bostrychia moriziana & $44.73(\mathrm{n}=32) \pm 33.99$ & $64(\mathrm{n}=32)$ & 55.05 & 0.78 & 20.22 \\
\hline \multicolumn{6}{|l|}{ Mangrove } \\
\hline \multicolumn{6}{|l|}{ Phylum Tracheophyta } \\
\hline Rhizophora mangle & $39.81(\mathrm{n}=9) \pm 33.66$ & $18(\mathrm{n}=9)$ & 24.33 & 0.54 & 7.88 \\
\hline Seagrass & & $24(\mathrm{n}=12)$ & & & \\
\hline \multicolumn{6}{|l|}{ Phylum Tracheophyta } \\
\hline Halophila sp. & $41.84(\mathrm{n}=12) \pm 33.73$ & & 29.84 & 0.66 & 10.67 \\
\hline Halodule sp. & $7.57(\mathrm{n}=1) \pm 0.00$ & $2(\mathrm{n}=1)$ & 14.80 & 0.33 & 0.86 \\
\hline \multicolumn{6}{|l|}{ Annelids } \\
\hline \multicolumn{6}{|l|}{ Phylum Annelida } \\
\hline $\begin{array}{l}\text { Amphicteis sp. } \\
\text { Artropodes }\end{array}$ & $29.82(\mathrm{n}=13) \pm 29.40$ & $26(n=13)$ & 41.09 & 0.91 & 12.04 \\
\hline \multicolumn{6}{|l|}{ Phylum Arthropoda } \\
\hline Copepods & $17.79(\mathrm{n}=3) \pm 20.37$ & $6(n=3)$ & 18.64 & 0.41 & 2.59 \\
\hline \multicolumn{6}{|l|}{ Mollusks } \\
\hline \multicolumn{6}{|l|}{ Phylum Mollusca } \\
\hline $\begin{array}{l}\text { Cerithium sp. } \\
\text { Jellyfish }\end{array}$ & $29.37(\mathrm{n}=25) \pm 23.71$ & $50(\mathrm{n}=25)$ & 59.57 & 0.68 & 13.08 \\
\hline Phylum Cnidaria & $46.83(\mathrm{n}=6) \pm 41.96$ & $12(\mathrm{n}=6)$ & 14.37 & 0.32 & 5.15 \\
\hline Sponges & & & & & \\
\hline Phylum Porifera & & & & & \\
\hline Mycale sp. & $20.90(\mathrm{n}=1) \pm 0.00$ & $24(\mathrm{n}=12)$ & 48.95 & 0.91 & 9.68 \\
\hline Geodia sp. & $77.49(\mathrm{n}=1) \pm 0.00$ & $8(n=8)$ & 5.89 & 0.13 & 3.40 \\
\hline
\end{tabular}

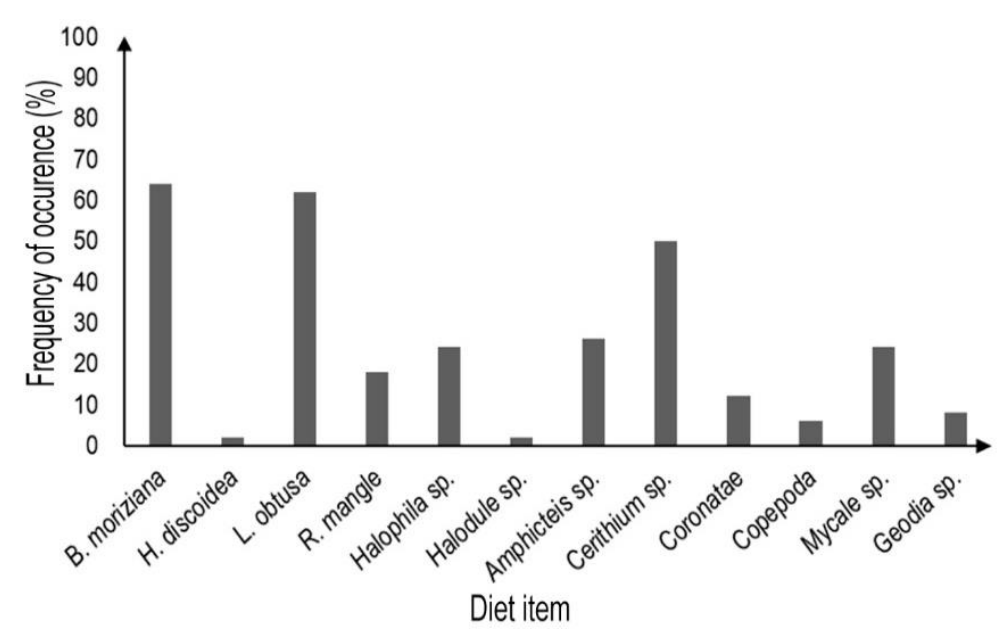

Figure 3. Frequency of occurrence of items found in esophageal lavages.

We were able to monitor temporal changes in SI values for turtles that were recaptured on more than one occasion during this study (Fig. 5). We found that $\delta^{13} \mathrm{C}$ and $\delta^{15} \mathrm{~N}$ were consistent in plasma for recaptured turtles, were the mean $\delta^{13} \mathrm{C}$ was $-18.1593 \pm 0.1 \%$, and mean $\delta^{15} \mathrm{~N}$ was $7.9 \pm 0.06 \%$. However, SI values of skin varied among capture events for two individuals. 


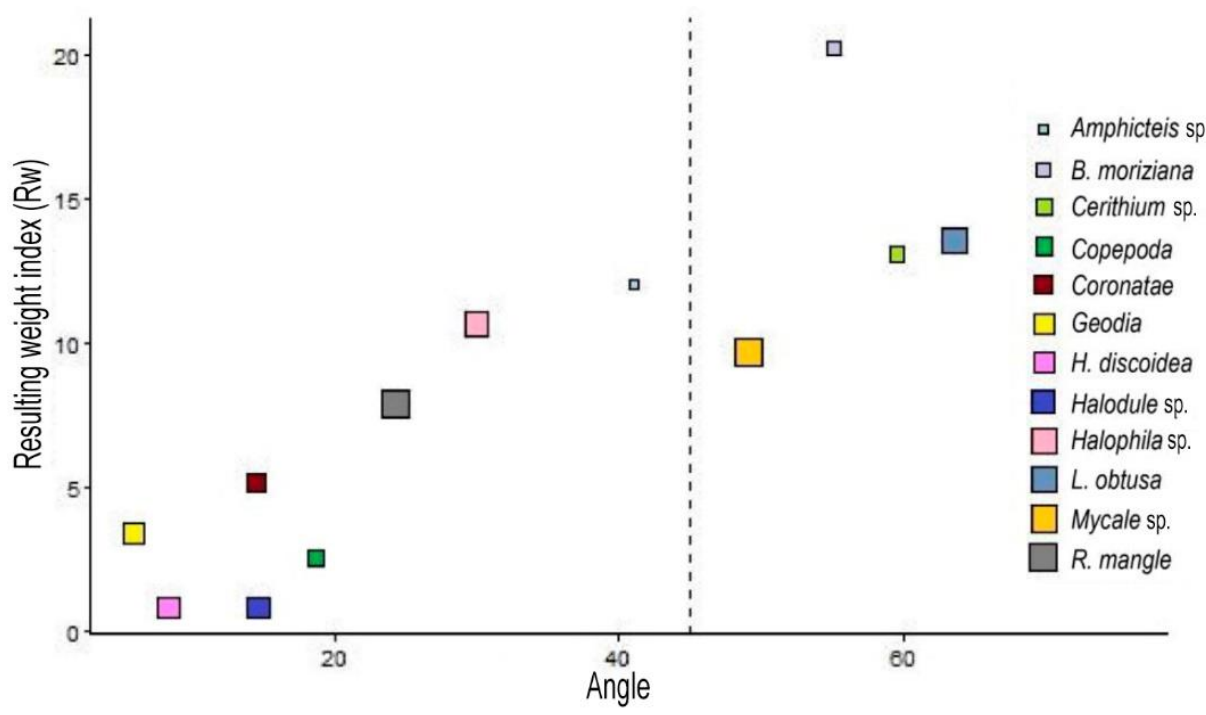

Figure 4. Importance ( $\mathrm{Rw})$ of the primary dietary components (i.e., mean \% VO > 5) for hawksbills turtles Eretmochelys imbricata in Golfo Dulce, Costa Rica. Order of importance (from most-to-least important) is Bostrychia moriziana > Laurencia obtusa > Cerithium sp. > Amphicteis sp. > Halophila sp. > Mycale sp. > Rhizophora mangle > Coronatae > Geodia sp. > Copepoda > Halodule sp. > Halimeda discoidea.
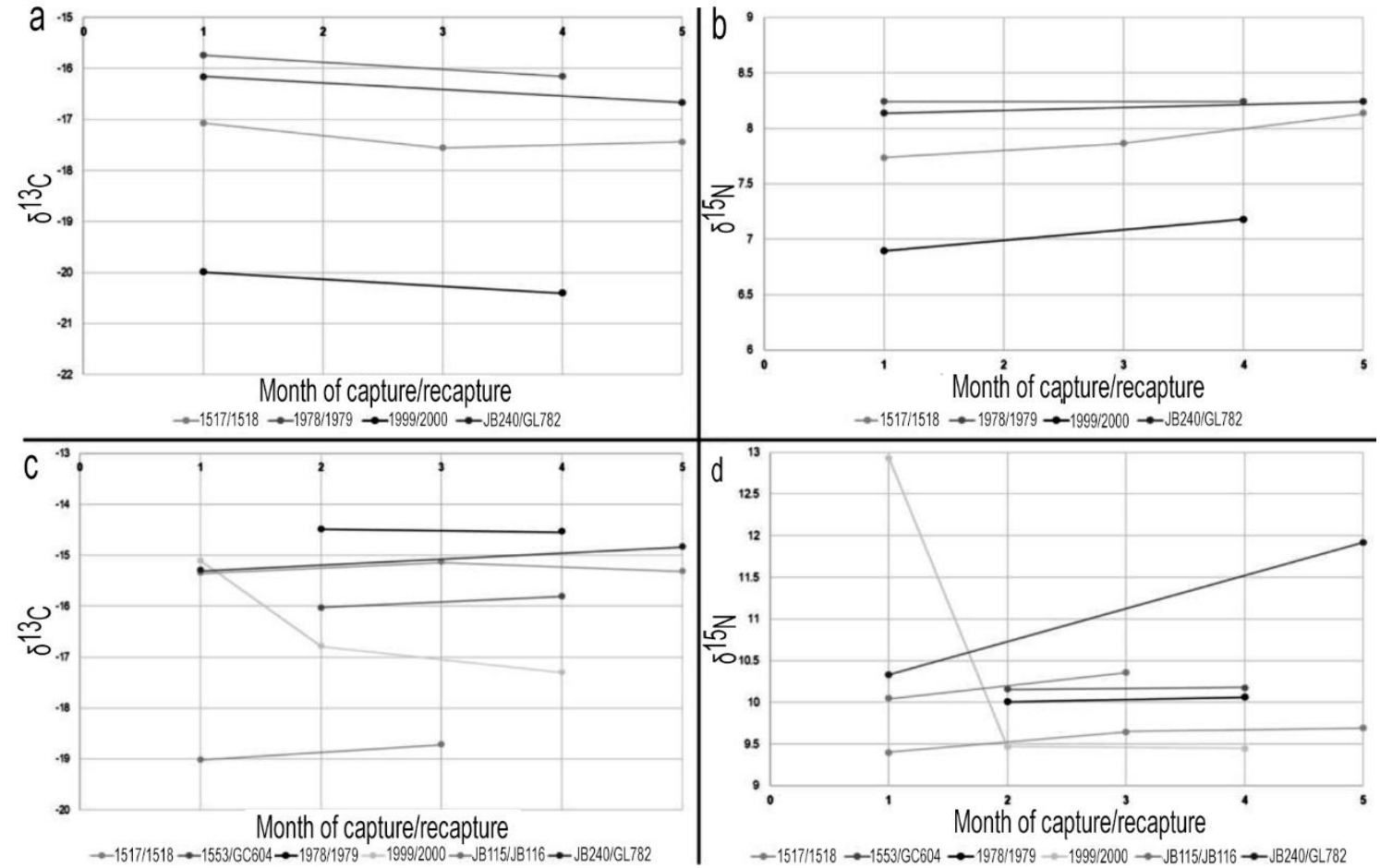

Figure 5. Stable isotope values $\left(\delta^{13} \mathrm{C}\right.$ and $\delta^{15} \mathrm{~N}$, in \%o) in hawksbill turtles (Eretmochelys imbricata) plasma $(\mathrm{a}, \mathrm{b} ; \mathrm{n}=4)$ and skin (c,d; $n=6)$ corresponding to first capture and recaptures of hawksbill turtles in Golfo Dulce, Costa Rica. Stable isotope values are given according to the month of capture: 1) March, 2) April, 3) May, 4) June, 5) July.

For turtle 1999/2000, changes occurred between the first (March 27, 2015) and second (July 13, 2015) captures, with a $\delta^{13} \mathrm{C}$ changing from -15.1 to $-16.8 \%$ 。 and $\delta^{15} \mathrm{~N}$ from 12.9 to $9.5 \%$. Turtle JB240/GL782 also showed variation between its first (March 3, 2015) to its last capture (July 23, 2015), with $\delta^{13} \mathrm{C}$ changing from -15.3 to $-14.8 \%$, and $\delta^{15} \mathrm{~N}$ changing from 10.3 to $11.9 \%$. 
Table 5. Mean elemental concentrations $\left(\% \mathrm{C}, \% \mathrm{~N}\right.$, in $\%$ ) and stable isotope values $\left(\delta^{15} \mathrm{~N}, \delta^{13} \mathrm{C}\right)$ for plasma and skin samples of hawksbill turtles Eretmochelys imbricata collected from March to August 2015 in Golfo Dulce, Costa Rica. SD: standard deviation. $\mathrm{n}$ : number of individuals.

\begin{tabular}{|c|c|c|c|c|c|c|c|c|c|}
\hline \multirow{2}{*}{ Month } & \multirow{2}{*}{$\mathrm{n}$} & \multicolumn{2}{|c|}{$\% \mathrm{C}$} & \multicolumn{2}{|c|}{$\% \mathrm{~N}$} & \multicolumn{2}{|c|}{$\delta^{13} \mathrm{C}(\%)$} & \multicolumn{2}{|c|}{$\delta^{15} \mathrm{~N}(\%)$} \\
\hline & & Mean \pm SD & Range & Mean \pm SD & Range & Mean \pm SD & Range & Mean \pm SD & Range \\
\hline \multicolumn{10}{|l|}{ Plasma } \\
\hline March & 9 & $42.5 \pm 1.7$ & 40.6 to 45.6 & $11.1 \pm 0.4$ & 10.4 to1 1.6 & $-18.2 \pm 1.7$ & -20.8 to -15.7 & $7.6 \pm 0.4$ & 6.9 to 8.2 \\
\hline April & 2 & $42.6 \pm 0.3$ & 42.3 to 42.9 & $10.6 \pm 0.1$ & 10.5 to 10.7 & $-18.3 \pm 1.2$ & -19.6 to -17.1 & $7.7 \pm 0.3$ & 7.4 to 8.0 \\
\hline May & 11 & $41.7 \pm 2.3$ & 36.0 to 45.1 & $10.6 \pm 0.8$ & 9.2 to 11.7 & $-19.3 \pm 1.8$ & -23.0 to -16.8 & $7.9 \pm 0.9$ & 7.0 to 10.4 \\
\hline June & 7 & $42.7 \pm 0.9$ & 41.2 to 43.9 & $10.9 \pm 0.3$ & 10.3 to 11.3 & $-17.7 \pm 1.6$ & -20.4 to- 15.9 & $7.8 \pm 0.3$ & 7.2 to 8.2 \\
\hline July & 14 & $42.6 \pm 1.6$ & 40.1 to 45.4 & $10.8 \pm 0.5$ & 9.8 to 11.4 & $-17.7 \pm 1.4$ & -22.1 to -15.9 & $7.8 \pm 0.3$ & 7.5 to 8.5 \\
\hline \multicolumn{10}{|l|}{ Skin } \\
\hline March & 6 & $38.4 \pm 1.2$ & 37.4 to 40.8 & $13.5 \pm 0.6$ & 12.8 to 14.7 & $-16.6 \pm 1.5$ & -19.0 to -15.1 & $10.1 \pm 1.0$ & 9.3 to 12.2 \\
\hline April & 3 & $38.8 \pm 2.4$ & 35.6 to 41.2 & $13.7 \pm 0.8$ & 12.5 to 14.4 & $-15.8 \pm 1.0$ & -16.8 to- -14.5 & $9.9 \pm 0.3$ & 9.5 to 10.2 \\
\hline May & 9 & $40.0 \pm 1.5$ & 37.9 to 42.9 & $14.4 \pm 0.7$ & 13.1 to 15.3 & $-16.4 \pm 1.9$ & -20.4 to -14.6 & $10.0 \pm 0.5$ & 9.4 to 10.8 \\
\hline June & 8 & $39.3 \pm 2.3$ & 37.2 to 44.5 & $13.9 \pm 0.8$ & 13.2 to 15.7 & $-15.4 \pm 1.0$ & -16.8 to- 13.9 & $10.0 \pm 0.5$ & 9.3 to 11.0 \\
\hline July & 4 & $39.3 \pm 2.8$ & 34.7 to 41.9 & $13.5 \pm 0.7$ & 12.4 to 14.3 & $-15.1 \pm 0.4$ & -15.6 to- 14.4 & $9.9 \pm 0.2$ & 9.7 to 10.3 \\
\hline
\end{tabular}

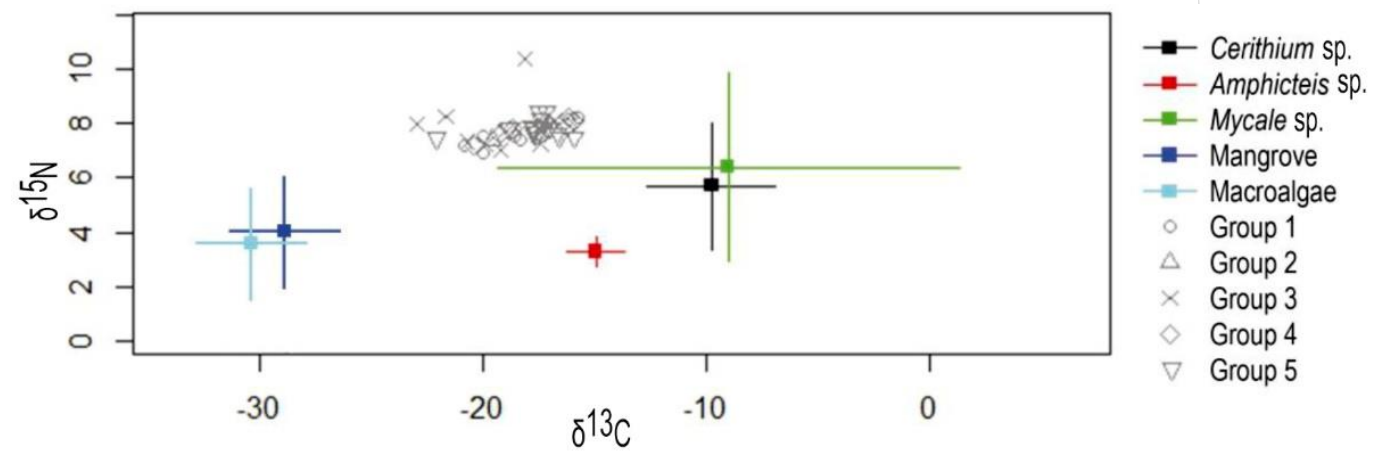

Figure 6. Plasma isotopic values (\%o) of hawksbills turtles Eretmochelys imbricata in Golfo Dulce, Costa Rica, plotted with isotope values of possible food sources. Open symbols represent turtle values; each group reflects one month of study (Group 1: March, Group 2: April, Group 3: May, Group 4: June, Group 5: July). Filled squares represent prey item mean values and variance.

Among the potential foods, $\delta^{13} \mathrm{C}$ ranged from -30.7 to $-9.3 \%$ and $\delta^{15} \mathrm{~N}$ ranged from 3.0 to $6.1 \%$. Lower values of $\delta^{13} \mathrm{C}$ and $\delta^{15} \mathrm{~N}$ were observed for marine algae, whereas invertebrates, except for Amphicteis sp., had higher values; Mycale sp. was the most enriched in both ${ }^{13} \mathrm{C}$ and ${ }^{15} \mathrm{~N}$ (Table 5; Figs. 6-7).

The proportional contributions of all possible prey species were modeled with SIAR (Figs. 8, 9), and the contribution of each item ranged from 0 to $62 \%$ (Table 6). For models based on skin $\delta^{13} \mathrm{C}$ and $\delta^{15} \mathrm{~N}$ values, snail (Cerithium sp.) was the invertebrate with the highest dietary contribution, with a proportional contribution range of 1 to $63 \%$ (mean $=38 \%)$. Mangrove $(R$. mangle, $P$. rhizophorae and A. germinans) and sponge (Mycale sp.) had the largest contributions based on their contribution percentages for both plasma and skin. Mangrove contributions based on plasma and skin model outputs were from 1 to $50 \%$ (mean $=30 \%)$ and from 0 to $42 \%$ (mean $=30 \%)$, respectively. The dietary contribution values for Mycale sp. were 0 to $59 \%$ (mean $=25 \%$ ) based on plasma SI values, and from 2 to $40 \%$ $($ mean $=23 \%)$ based on skin SI values.

When evaluated by month, proportional contributions based on plasma SI values showed that Cerithium sp., Mycale sp., mangroves and macroalgae were consistent in the diet throughout the study (from 0 to 63\%). The excavating worm (Amphicteis sp.) had relatively smaller contributions throughout the study (0 to $38 \%$ ) and was similar in its importance to these other prey items only during April (Fig. 10).

For skin tissue-derived dietary proportional calculations, the contribution of Cerithium sp. was generally constant, with a peak observed in June. In May, a decrease in the contribution by Amphicteis sp. was observed, whereas the biggest contributor was Mycale sp. As our study progressed from March to July, 


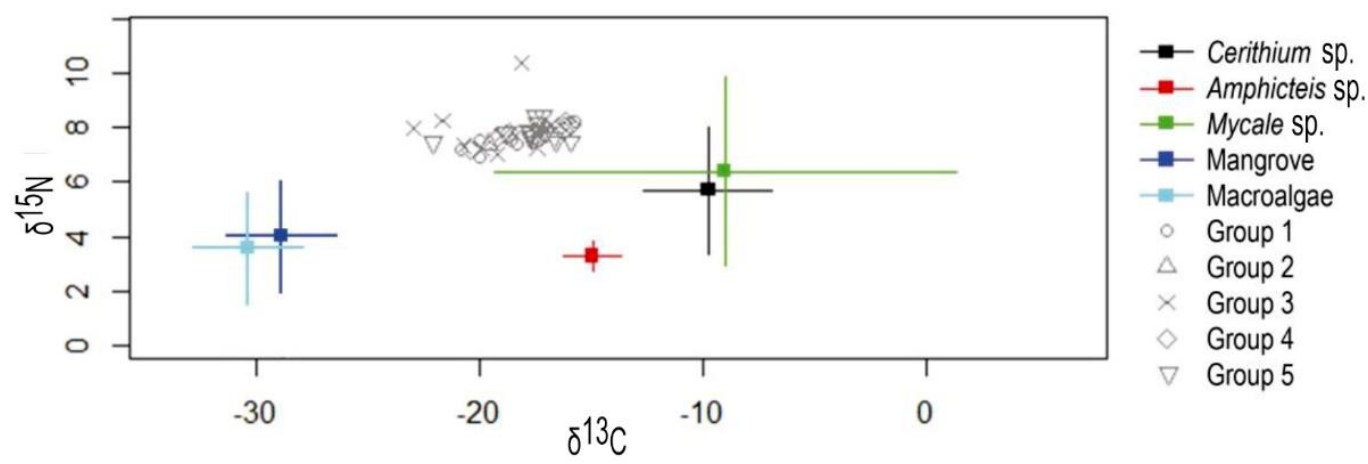

Figure 7. Skin isotope values (\%o) of hawksbills Eretmochelys imbricata in Golfo Dulce, Costa Rica, plotted with isotope values of possible food sources. Open symbols represent turtle values; each group reflects one month of study (Group 1: March, Group 2: April, Group 3: May, Group 4: June, Group 5: July). Filled squares represent prey item mean values and variance.

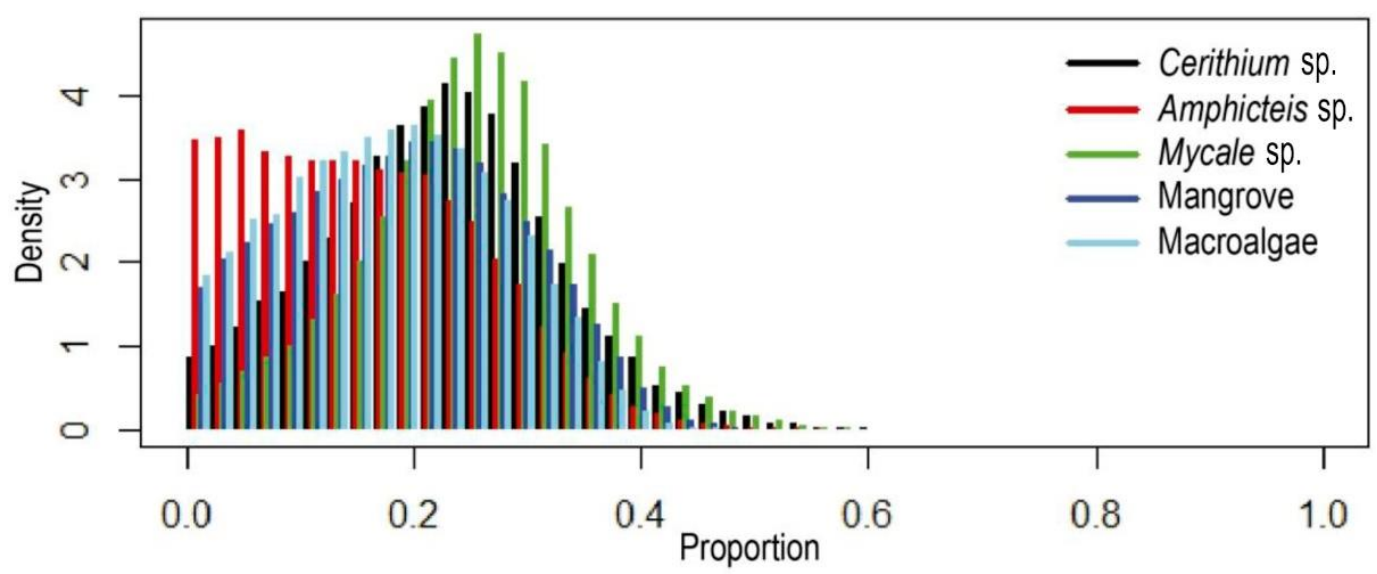

Figure 8. SIAR histogram projection incorporating the discrimination factors from Reich et al. (2008) in plasma of sampled hawksbill turtles Eretmochelys imbricata and the distribution of the contribution of the five possible diet sources for the period of March to August 2015 in Golfo Dulce, Costa Rica.

Cerithium sp., Mycale sp. and Amphicteis sp. were relatively consistent in hawksbill diet $(25 \%$ average contribution). During the same period, the dietary contribution for mangrove decreased from 21 to $18 \%$ and for macroalgae decreased from 20 to $15 \%$ during the same period (Fig. 11).

\section{DISCUSSION}

This is the first study to combine oesophageal lavage and stable nitrogen and carbon isotope analyses in eastern Pacific sea turtles, and to our knowledge is also the first-ever published stable isotope study for hawksbills in this region. The information obtained in this research contributes to the knowledge of the foraging behaviour and general biology of hawksbills (Gaos et al., 2012b; Carrión et al., 2013; Heidemeyer et al., 2014; Chacón et al., 2015; Llamas et al., 2017), and our data show that coastal waters of Golfo Dulce offer important shelter and food for this critically endangered species (Gaos et al., 2011; Carrión et al., 2013). Moreover, the hawksbill's apparent fidelity to this area-as evidenced by numerous recapturesunderscores the need to protect the habitats and prey resources present in Golfo Dulce (Chacón et al., 2015).

The CPUE for our study ( 0.2 turtles/ $6 \mathrm{~h}$ ) is higher than that reported in previous research in the area (Chacón et al., 2015) and together with the numerous recaptures indicates a stable resident population of both juveniles and adults. The presence of a $39.5 \mathrm{~cm}$ (CCL) individual suggests this site hosts hawksbills that have recently recruited from open ocean habitats. Postoceanic juveniles have also been reported at other areas along the Pacific coast including Punta Coyote (minimum CCL 36 cm; Carrión et al., 2013), Matapalito Bay (minimum CCL $=31 \mathrm{~cm}$ ), in the Gulf of Nicoya (Heidemeyer et al., 2014), and Coiba National Park (minimum CCL $=30 \mathrm{~cm}$ ) (Llamas et al., 2017). 


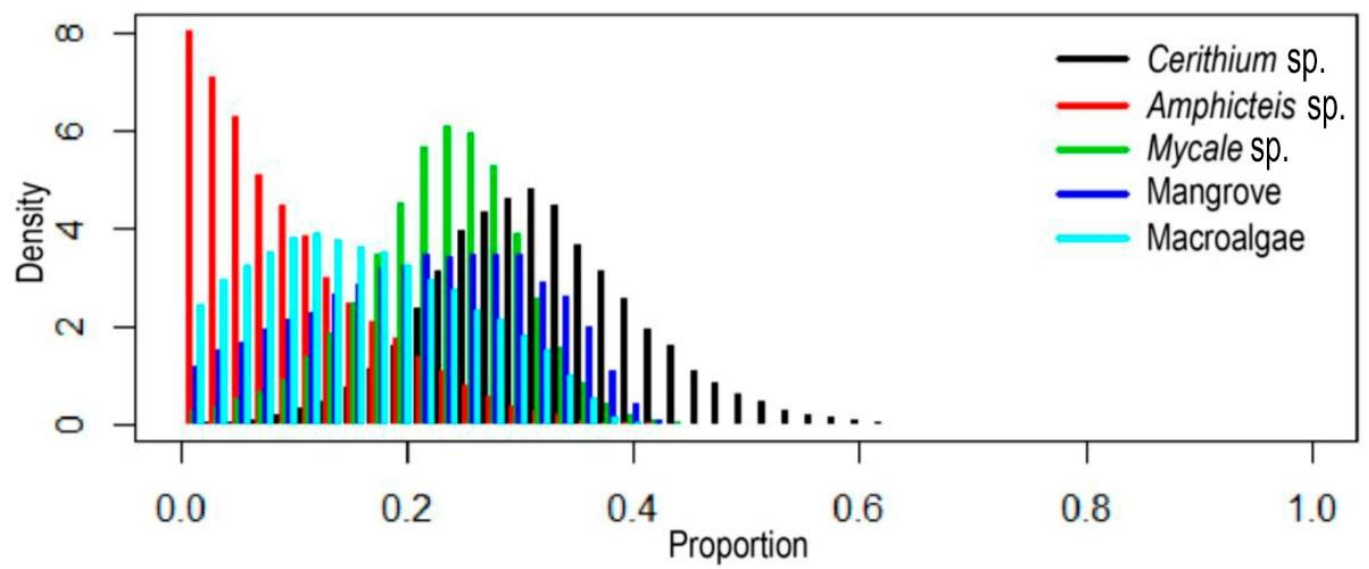

Figure 9. SIAR histogram projection incorporating the discrimination factors from Reich et al. (2008) in the skin of sampled hawksbill turtles Eretmochelys imbricata and the distribution of the contribution of the five possible diet sources for the period of March to August 2015 in Golfo Dulce, Costa Rica.

Table 6. Proportional contributions of putative prey species obtained with SIAR.

\begin{tabular}{lccccc}
\hline \multirow{2}{*}{ Species } & \multicolumn{2}{c}{ Plasma } & & \multicolumn{2}{c}{ Skin } \\
\cline { 2 - 3 } \cline { 5 - 6 } & $\begin{array}{c}\text { Contribution } \\
\text { range }(\%)\end{array}$ & Mean & $\begin{array}{c}\text { Contribution } \\
\text { range }(\%)\end{array}$ & Mean \\
\hline Cerithium sp. & 1 to 63 & 24 & & 1 to 63 & 38 \\
Amphicteis sp. & 0 to 59 & 15 & & 0 to 38 & 10 \\
Mycale sp. & 0 to 59 & 25 & & 0 to 42 & 22 \\
Mangrove & 1 to 50 & 30 & & 0 to 41 & 21 \\
Macroalgae & 1 to 45 & 20 & & 0 to 43 & 10 \\
\hline
\end{tabular}

Coupled with our data, these observations indicate that eastern Pacific hawksbills recruit to coastal habitats with a CCL $\geq 30 \mathrm{~cm}$, and show that the Pacific coast of Costa Rica is an important area for juveniles recruiting to coastal habitats after completing their oceanic juvenile phase.

It cannot be established if there is a life stage-based (i.e., juvenile vs. adult) habitat preference. However, our results suggest that coastal estuaries and mangrove forests are especially important for adult hawksbills (Fig. 3), a finding that is consistent with data from El Salvador and Pacific Nicaragua (Gaos et al., 2010, 2011, 2012a, 2012b), as well as from and the Guanacaste coast of Costa Rica (Carrión et al., 2013). In Golfo Dulce, the use of mangrove forests may be a way to compensate for the regional progressive loss of coral reef ecosystems (Cortés et al., 2010), as these mangrove forests offer vertical structure that may provide protection from predators, much like coral reefs.

All hawksbills were captured in waters of $7 \mathrm{~m}$ or shallower. This pattern has been reported for other sites in the EP (Diez et al., 2003; Gaos et al., 2012a, 2016; Carrión et al., 2013; Llamas et al., 2017), indicating that they live in shallow areas, likely related to food availability, with greater food densities and diversity in shallow waters (Meylan, 1988; León \& Bjorndal, 2002; Carrión et al., 2013).

From our lavage efforts, macroalgae were highlighted as the prey type having the highest frequency of occurrence and importance based on the Rw, with $B$. moriziana the most significant diet item $(\mathrm{Rw}=20.22)$. This may be related to macroalgae's abundance and association to the rocky substrate where large numbers of invertebrates inhabit (Ward et al., 1999). The consumption of invertebrates such as Cerithium sp. and Amphicteis sp. is relevant, and these are likely important dietary alternatives where sponges are not abundant (León \& Bjorndal, 2002). The fact that both marine algae and invertebrates were found in the lavage samples in more than trace amounts underscores the generalist foraging strategy of hawksbill turtles in Golfo Dulce, which may be consistent with food availability scenarios at other sites in the EP (Gaos et al., 2006, 2010, 2011, 2012a).

Applying stable isotope analyses for the first time ever in EP hawksbills, we were able to confirm that in addition to merely consuming a mixed diet, these turtles are also assimilating the nutrients garnered from these diverse food sources. Indeed, the SIAR mixing model results indicate that all the analysed potential diet items contribute to hawksbill diet and nutrition in Golfo Dulce (Figs. 9-10). This strongly contrasts with hawksbills in the Caribbean that almost exclusively consume sponges and only occasionally forage on invertebrates (Meylan, 1988; León \& Bjorndal, 2002; Parker et al., 2009; Bell, 2012). 


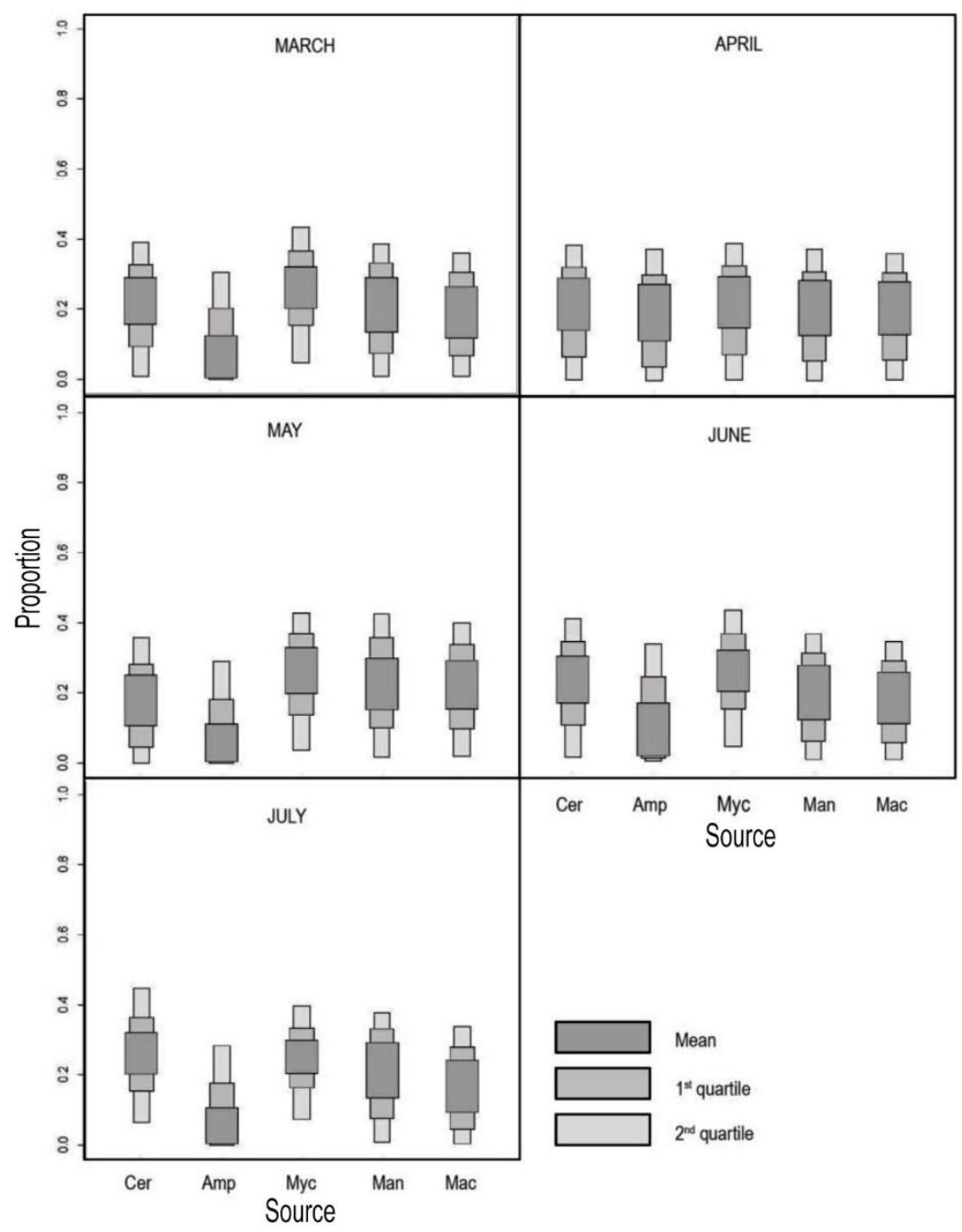

Figure 10. SIAR illustration showing the contribution ranges for the diet of hawksbill turtles Eretmochelys imbricata by the diet items from March to July 2015 in Golfo Dulce, Costa Rica. Cer: Cerithium sp., Amp: Amphicteis sp., Myc: Mycale sp., Man: mangrove, Mac: macroalgae.

The identification of the sponges Mycale sp. and Geodia sp. in the oesophageal lavage samples, although not found in great quantity, indicates that hawksbills in this study consumed at least some sponges. However, the SIAR outputs for both blood plasma and skin indicate a greater dietary importance for Mycale sp. than suggested by our lavage results. The disparity in the results may be related with the sponge tissue being assimilated during digestive processes to a greater extent than other consumed prey species or perhaps due to difficulty retrieving this prey type via the lavage technique.

The five months of data collection allow us to evaluate temporal consistency in hawksbills trophic status (Figs. 11-12). The sponge Mycale sp. and the snail Cerithium sp. were constant diet sources, and the latter was a constant diet component and the biggest contributor to hawksbills diet during this study. Isotope values from bulk skin tissue, which provide a ca. 4- to 5-month dietary retrospective, suggest that prior to our sampling period the intake and contribution of invertebrates was greater than that for algae and plant prey species. For plasma, our isotope results suggest that the consumption of macroalgae and mangrove increased during this study. Our results also suggest that invertebrates became less frequently consumed over the course of our research. Together, these observations may indicate a seasonal shift in the rate of ingestion of different food items, perhaps related to a change in resource abundance prior to, and during, our study. 


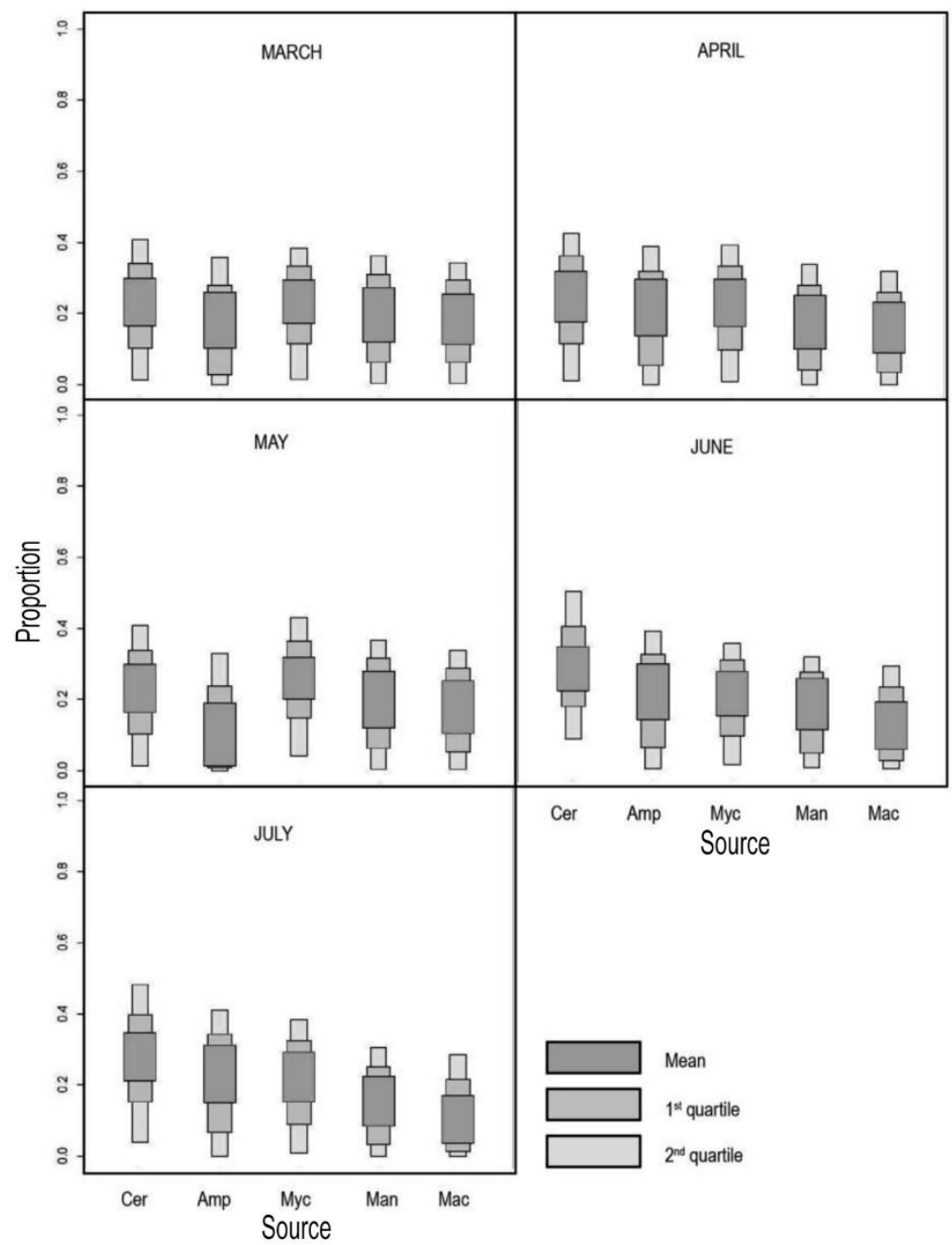

Figure 11. Monthly variation of the contribution ranges for the diet of the hawksbill Eretmochelys imbricata by the possible diet elements in the period of March to July 2015 in Golfo Dulce, Costa Rica. Cer: Cerithium sp., Amp: Amphicteis sp., Myc: Mycale sp., Man: mangrove, Mac: macroalgae.

Despite its high occurrence in lavage samples, the least consistent dietary component, as reflected in the plasma isotopes, was the excavating worm Amphicteis sp. This suggests relatively low nutrient assimilation from this prey item. The ingestion of Amphicteis sp. could be incidental, although its contribution of valuable nutrients for hawksbills cannot be ruled out. However, when gauging the importance of Amphicteis sp. and other diet constituents, we also acknowledge that the diet-tissue discrimination values from Reich $e t$ al. (2008) used in this study may not be ideal and perhaps resulted in the disparity between our lavage results and the SIAR model outputs. We therefore encourage dedicated studies of stable isotope discri- mination for hawksbill turtles to better inform future isotopic studies of this species in the EP and elsewhere.

Isotopic turnover is defined as the isotopic change due to growth and metabolic tissue replacement associated with a change in diet (MacAvoy et al., 2001), where skin tissue has a relatively slow turnover of 4-5 months (in Caretta caretta; Reich et al., 2008) and blood plasma has a turnover rate of approximately 35 days (in Trachemys scripta; Seminoff et al., 2007). In this research, when comparing $\delta^{13} \mathrm{C}$ and $\delta^{15} \mathrm{~N}$ values from hawksbills at the time of their initial capture vs. recapture(s) (Fig. 6), the plasma isotopic values remained constant, thus suggesting that their residency in this foraging area has been ongoing for at least a 
month prior to the first capture. Skin isotope values suggest the same pattern for the majority of individuals, signifying their residence for at least four months prior to the start of this study; however, two individuals showed notable changes in these values, suggesting that they may have recently recruited to Golfo Dulce. The individual identified with tag numbers 1999/2000 showed substantial changes in both nitrogen and carbon isotope values between the first and second captures ( $\delta^{15} \mathrm{~N}$ from 12.9 to $9.5 \%$ o, $\delta^{13} \mathrm{C}$ from -15.1 to $-16.8 \%$ ) . A second turtle (JB240/GL982), also showed different values, albeit to a lesser extent, between its initial and final capture $\left(\delta^{15} \mathrm{~N}\right.$ from 10.3 to $11.9 \%, \delta^{13} \mathrm{C}$ from- 15.3 to $-14.8 \%$ ). In both cases, the differing isotope values suggest that at first capture both turtles still possessed isotope values in their tissues that were reflective of habitats occupied prior to arriving in Golfo Dulce.

\section{CONCLUSIONS}

This is the first-ever report on the stable isotopederived diet profile for hawksbill turtles in the EP, and the results of this study increase our understanding of the nutritional ecology of this endangered species in Golfo Dulce. Indeed, our results, demonstrate that they forage on a large variety of prey species in this area. This generalist foraging tactic, compared to the species' diet in the Caribbean and other coral-dominated habitats, may also be the trophic strategy for hawksbills at other foraging grounds in the EP, particularly those containing mangrove estuaries. This feeding pattern and the fidelity to the Golfo Dulce foraging area, as substantiated via ongoing research in the area (e.g., Chacón et al. 2011; 2015), underscores the importance of protecting this region from human impacts, as its ecosystems are vulnerable to threats such as conversion into farm lands (Algeet et al., 2015; Gallmetzer \& Schulze, 2015) and climate change (Ghosh et al., 2015). In-water research and conser-vation efforts have been developing in the area, and the Costa Rican Fisheries and Aquaculture Institute (INCOPESCA) has declared the Golfo Dulce as a Responsible Marine Fisheries Area. This designation prohibits trawling, longlining, and trammel fishing, while at the same time regulates the type and size of hooks used for artisanal hook-and-line fishing. However, involvement of the community in both learning about, and protecting, this ecosystem and the species that inhabit it, are paramount to maintaining the pristine nature of this tropical fjord and its marine inhabitants. In the same light, this research indicates that further stable isotope studies should be conducted on this enigmatic EP population to complement information on habitat use and foraging behaviour, and to establish the predator-prey discrimination factors $\left(\Delta_{\mathrm{dt}}\right)$ for the species. By providing additional data for hawksbills in this and surrounding areas, this and future studies will provide a more robust view of hawksbill trophic ecology.

\section{ACKNOWLEDGMENTS}

We thank the Latin American Sea Turtle Association (LAST) (CJ-3-002-495589), Costa Rica, for providing the facilities, material, funding and research permits. We also thank LAST staff members Alice Mockford, David Rojas and Beth Pynnonen, research assistants Pascal Chabanne, Audrey Chabanne, Tom Gammage, Elena Horas, Callie Veelenturf, Nazik Elmekki, Heather Afford and Alba Caballol, and all the volunteers that gave their energy and support during this process. We gratefully acknowledge the Costa Rican Fisheries and Aquaculture Institute (INCOPESCA) for granting the research licenses under the AJDIP/127-2011 Agreement, the National System of Conservation Areas (SINAC) for approving the CITES Export Permit 2015-CR1585/SJ[\#S1648], the NOAASouthwest Fisheries Science Center for facili tating CITES importations (permit 14US844694/9), and the National Animal Health Service (SENASA) for providing the Animal Health Certificate (No. 30788). We thank the National University of Costa Rica, specifically the Regional Postgraduate in Veterinary Sciences, the Laboratory of Bacteriology, particularly to the researcher of doctorate Elías Baquero Calvo, the Regional Institute of Toxic Substances Studies, principally MSc Freylan Mena Torres, and the Department of Geosciences Stable Isotope Laboratory at University of Florida, for providing materials, analysis and making possible the ongoing of this investigation

\section{REFERENCES}

Algeet-Abarqueroab, N., Marchamaloa, M., Bonattic J., Fernández-Moya, J. \& Moussa, R. 20015. Implications of land use change on runoff generation at the plot scale in the humid tropics of Costa Rica. Catena, 135: 263-270

Arthur, K. \& Balazs, G. 2008. A comparison of immature green turtle (Chelonia mydas) diets among seven sites in the main Hawaiian Islands. Pacific Science, 62(2): 205-217.

Bell, I. 2012. Algivory in hawksbill turtles: Eretmochelys imbricata food selection within a foraging area on the northern Great Barrier Reef. Marine Ecology, 34: 113.

Blumenthal, J.M., Austin, T.J., Bell, C.D.L., Bothwell, J.B., Broderick, A.C., Ebanks-Petrie, G., Gibb, J.A., Luke, K.E., Olynik, J.R., Orr, M.F., Solomon, J.L. \& Godley, B.J. 2009. Ecology of hawksbill turtles, Eretmochelys imbricata, on a Western Caribbean 
foraging ground. Chelonian Conservation Biology, 8: $1-10$.

Carpentier, A., Booth, D., Arthur, K. \& Limpus, C. 2015. Stable isotope relationships between mothers, eggs, and hatchlings in loggerhead sea turtles Caretta caretta. Marine Biology, 162(4): 783-797.

Carrión, J., Canales, C., Arauz, R. \& Riosmena, R. 2013. Habitat use and diet of juvenile eastern Pacific hawksbill turtles (Eretmochelys imbricata) in the north Pacific coast of Costa Rica. Chelonian Conservation Biology, 12: 235-245.

Chacón, D., Martínez, S., Rojas, D. \& Fonseca, L. 2015. Golfo Dulce, Costa Rica, un área importante de alimentación para la tortuga carey del Pacífico Oriental (Eretmochelys imbricata). Revista de Biología Tropical, 63(1): 351-362.

Chacón, D., Rojas, D., Barash, A. \& Quesada, C. 2011. New Pacific green turtle foraging ground at Dulce Gulf, south Pacific coast of Costa Rica. In: Jones, T.T. \& Wallace, B.P. (Eds.). Proceedings of the Thirty-first Annual Symposium on Sea Turtle Biology \& Conservation. NOAA Technical Memorandum, NOAA NMFS-SEFSC-631, 306 pp.

Cortés, J. 1991. Los arrecifes coralinos de Golfo Dulce, Costa Rica: aspectos geológicos. Revista Geológica de América Central, 13: 15-24.

Cortés, J., Jiménez, C., Fonseca, A. \& Alvarado, J. 2010. Status and conservation of coral reefs in Costa Rica. Revista de Biología Tropical, 58(1): 33-55.

Diez, C., Vélez, X. \& Van Dam, R. 2003. Hawksbill turtles in seagrass beds. Marine Turtle Newsletter, 102: 8-10.

Espinoza, M., Munroe, S., Clarke, T., Fisk, A. \& Wehrtmann, I. 2015. Feeding ecology of common demersal elasmobranch species in the Pacific coast of Costa Rica inferred from stable isotope and stomach content analyses. Journal of Experimental Marine Biology and Ecology, 470: 12-25.

Forbes, G. 1999. Diet sampling and diet component analysis. In: Eckert, K., Bjorndal, K., Abreu, A. \& Donnelly, M. (Eds.). Research and management techniques for the conservation of sea turtles. SSC/IUCN Marine Turtle Specialist Group, Pennsylvania, pp. 1-5.

Gallmetzer, N. \& Schulze, C.H. 2015. Impact of oil palm agriculture on understory amphibians and reptiles: a Mesoamerican perspective. Global Ecology and Conservation, 4: 95-109.

Gannes, L., Martínez del Río, C. \& Koch, P. 1998. Natural abundance variations in stable isotopes and their potential uses in animal physiological ecology. Comparative Biochemistry and Physiology, 119(3): 725-737.
Gaos, A., Arauz, R. \& Yañez, I. 2006. Hawksbill turtles on the Pacific coast of Costa Rica. Marine Turtle Newsletter, 112(14): 1-2.

Gaos, A., Lewinson, R., Wallace, B., Yañez, I., Liles, M., Baquero, A. \& Seminoff, J. 2012a. Dive behaviour of adult hawksbills (Eretmochelys imbricata, Linnaeus 1766) in the eastern Pacific Ocean highlights shallow depth used by the species. Journal of Experimental Marine Biology and Ecology, 432-433: 117-178.

Gaos, A., Lewison, R., Wallace, B., Yañez, I., Liles, M., Nichols, W., Baquero, A., Hasbún, C., Vasquez, M., Urteaga, J. \& Seminoff, J. 2012b. Spatial ecology of critically endangered hawksbill turtles Eretmochelys imbricata: implications for management and conservation. Marine Ecology Progress Series, 450: 181-194.

Gaos, A., Lewison, R., Yañez, I., Wallace, B., Liles, M., Nichols, W., Baquero, A., Hasbún, C., Vasquez, M., Urteaga, J. \& Seminoff, J. 2011. Shifting the lifehistory paradigm: discovery of novel habitat uses by hawksbill turtles. Biology Letters, 8: 1-3.

Gaos, A., Abreu-Grobois, F., Alfaro, J., Amorocho, D., Arauz, R., Baquero, A., et al. 2010. Signs of hope in the eastern Pacific: international collaboration reveals encouraging status for a severely depleted population of hawksbill turtles Eretmochelys imbricata. Oryx, 44(4): 595-601.

Gaos, A., Lewison R., Liles M., Gadea V., Altamirano E., Henríquez A., et al. 2016. Hawksbill turtle terra incognita: conservation genetics of eastern Pacific rookeries. Ecology and Evolution, 6(4): 1251-1264.

Gaos, A.R., Liles, M.J., Gadea, V., Peña de Niz, A., Vallejo, F., Miranda, C., et al. 2017. Living on the edge: hawksbill turtle nesting and conservation along the Eastern Pacific rim. Latin American Journal of Aquatic Research, 45(3): 572-584.

Ghosh, S., Bakshi, M., Bhattacharyya, S., Nath, B. \& Chaudhuri, P. 2015. A review of threats and vulnerabilities to mangrove habitats: with special emphasis on east coast of India. Journal of Earth Science and Climatic Change, 6(4): 1000270.

Godley, B.J., Thompson, D.R., Waldron, S. \& Furness, R.W. 1998. The trophic status of marine turtles as determined by stable isotope analysis. Marine Ecology Progress Series, 166: 277-284.

Hamann, M., Godfrey, M.H., Seminoff, J.A., Arthur, K., Barata, P.C.R., Bjorndal, K.A., et al. 2010. Global research priorities for sea turtles: informing management and conservation in the $21^{\text {st }}$ century. Endangered Species Research, 11: 245-269.

Heidenmeyer, M., Arauz, R. \& López, E. 2014. New foraging grounds for hawksbill (Eretmochelys imbricata) and green turtles (Chelonia mydas) along the northern Pacific coast of Costa Rica, Central 
America. Revista de Biología Tropical, 62(4): 109118.

Hobbie, E. \& Werner, R. 2004. Intramolecular, compound-specific, and bulk carbon isotope patterns in $\mathrm{C}_{3}$ and $\mathrm{C}_{4}$ plants: a review and synthesis. New Phytologist, 161: 371-385.

International Union for Conservation of Nature and Natural Resources (IUCN). 2017. IUCN Red list of threatened species. [www.iucnredlist.org]. Reviewed: June 10, 2019.

Jones, T.T. \& Seminoff, J.A. 2013. Feeding biology. Advances from field-based observations, physiological studies, and molecular techniques. In: Wyneken, J., Lohmann, K. \& Musick, J. (Eds.). The biology of sea turtles. CRC Press, Florida, pp. 211-248.

Labrada, V. 2011. Evaluación del estado de la salud de la tortuga verde del Pacífico Oriental (Chelonia mydas) que habita en la costa de Baja California Sur, a través de biomarcadores fisiológicos. Tesis de Doctorado, Centro de Investigaciones Biológicas del Noroeste, S.C., La Paz, México.

Lemons, G.E., Eguchi, T., Lyon, B.N., LeRoux \& R., Seminoff, J.A. 2012. Effects of blood anticoagulants on stable isotope values of sea turtle blood tissue. Aquatic Biology, 14: 201-206.

Lemons, G., Lewison, R., Komoroske, L., Gaos, A., Lai, C., Dutton, P., Eguchi, T., LeRoux, R. \& Seminoff, J. 2011. Trophic ecology of green sea turtles in a highly urbanized bay: Insights from stable isotopes and mixing models. Journal of Experimental Marine Biology and Ecology, 405: 25-32.

León, Y. \& Bjorndal, K. 2002. Selective feeding in the hawksbill turtle, an important predator in coral reef ecosystems. Marine Ecology Progress Series, 245: 249-258.

León, R. \& Vargas, J. 1998. Macro infauna of a tropical fjord-like embayment: Golfo Dulce, Costa Rica. Revista de Biología Tropical, 46(6): 81-90.

Lepoint, G., Dauby, P. \& Gobert, S. 2004. Applications of $\mathrm{C}$ and $\mathrm{N}$ stable isotopes to ecological and environmental studies in seagrass ecosystems. Marine Pollution Bulletin, 49(11-12): 887-891.

Llamas, I., Flores, E.E., Abrego, M.E., Seminoff, J.A., Hart, C.E., Donadi, R., Peña, B., Alvarez, G., Poveda, W., Amorocho, D.F. \& Gaos, A. 2017. Distribution, size range, and growth rates of hawksbill turtles at a major foraging ground in the eastern Pacific Ocean. Latin American Journal of Aquatic Research, 45(3): 597-605.

MacAvoy, S., Macko, S. \& Garman, G. 2001. Isotopic turnover in aquatic predators: quantifying the exploitation of migratory prey. Canadian Journal of Fisheries and Aquatic Sciences, 58: 923-932.
Mancini, A., Elsadek, I. \& Madon, B. 2015. When simple is better: comparing two sampling methods to estimate green turtles abundance at coastal feeding grounds. Journal of Experimental Marine Biology and Ecology, 465, 113-120.

McClellan, C., Braun-McNeill, J., Avens, L., Wallace, B. \& Read, A. 2010. Stable isotopes confirm a foraging dichotomy in juvenile loggerhead sea turtles. Journal of Experimental Marine Biology and Ecology, 387: 44-51.

Meylan, A. 1988. Spongivory in hawksbill turtles: a diet of glass. Science, 239(4838): 393-395.

Mohan, M.V. \& Sankaran, T.M. 1988. Two new indices for stomach content analysis of fishes. Journal of Fish Biology, 33: 289-292.

Morales, A. 2010. La diversidad marina del Golfo Dulce, Pacífico Sur de Costa Rica: amenazas a su conservación. Biocenosis, 24(1-2): 9-20.

Owens, D. \& Ruiz, G. 1980. New methods of obtaining blood and cerebrospinal fluid from marine turtles. Herpetologica, 36(1): 17-20.

Parker, D., Balazs, G., King, C., Katahira, L. \& Gilmartin, W. 2009. Short-range movements of hawksbill turtles (Eretmochelys imbricata) from nesting to foraging areas within the Hawaiian Islands. Pacific Science, 63(3): 371-382.

Rees, A.F., Alfaro-Shigueto, J., Barata, P.C.R., Bjorndal, K.A., Bolten, A.B., Bourjea, J., Broderick, A.C., et al . 2016. Are we working towards global research priorities for management and conservation of sea turtles? Endangered Species Research, 31: 337-382.

Reich, K. \& Seminoff, J. 2010. Standardizing sample collection, preparation, and analysis of stable isotopes of carbon and nitrogen in sea turtle research. Proceedings of the thirty-first annual symposium on sea turtle biology \& conservation. NOAA Technical Memorandum, NOAA NMFS-SEFSC-631, 306 pp.

Reich, K., Bjorndal, K. \& Martínez del Río, C. 2008. Effects of growth and tissue type on the kinetics of ${ }^{13} \mathrm{C}$ and ${ }^{15} \mathrm{~N}$ incorporation in a rapidly growing ectotherm. Oecologia, 155: 651-663.

Revuelta, O., Hawkes, L., León, Y.M., Godley, B.J., Raga, J.A. \& Tomás, J. 2015. Evaluating the importance of marine protected areas for the conservation of hawksbill turtle Eretmochelys imbricata nesting in the Dominican Republic. Endangered Species Research, 24: 169-180.

Samper, J., Bourg, A., Sibaja, J. \& Cortés, J. 2014. Presence of a Halophila baillonii Asch. (Hydrocharitaceae) seagrass meadow and associated macrofauna on the Pacific coast of Costa Rica. Pacific Science, 68(3): 1-22. 
Seminoff, J., Bjorndal, K. \& Bolten, A. 2007. Stable carbon and nitrogen isotope discrimination and turnover in pond sliders Trachemys scripta: insights for trophic study of freshwater turtles. Copeia, 2007: 534-542.

Seminoff, J., Resendiz, A. \& Nichols, W. 2002. Diet of east Pacific green turtles (Chelonia mydas) in the central Gulf of California, Mexico. Journal of Herpetology, 36(3): 447-453.

Seminoff, J., Nichols, W., Resendiz, A. \& Brooks, L. 2003. Occurrence of hawksbill turtles, Eretmochelys imbricata (Reptilia: Cheloniidae), near the Baja California Peninsula, Mexico. Pacific Science, 57(1): 9-16.

Seminoff, J., Jones, T., Eguchi, T., Jones, D. \& Dutton, P. 2006. Stable isotope discrimination $\left(\delta^{13} \mathrm{C}\right.$ and $\left.\delta^{15} \mathrm{~N}\right)$ between soft tissues of the green sea turtle Chelonia mydas and its diet. Marine Ecology Progress Series, 308: 271-278.

Seminoff, J., Benson, S., Arthur, K., Eguchi, T., Dutton, P., Tapilatu, R. \& Popp, B. 2012. Stable isotope tracking of endangered sea turtles: validation with satellite telemetry and $\delta^{15} \mathrm{~N}$ analysis of amino acids. Plos One, 7(5): 1-11.

Stokes, L. \& Epperly, S. 2008. Sea turtles research techniques manual. NOAA Technical Memorandum NMFS-SEFSC-579. U.S. Department of Commerce, Miami.

Strick, N., Alleman, A.R. \& Harr, K.E. 2007. Circulating inflammatory cells. In: Jacobson, E.R. (Ed.). Infectious diseases and pathology of reptiles. CRC Press Taylor \& Francis Group, Florida, pp. 167-218.

Received: 26 December 2018; Accepted: 8 November 2019
Svendsen, H., Rosland, R., Myking, S., Vargas, J.A., Lizano, O.G. \& Alfaro, E.J. 2006. A physicaloceanographic study of Golfo Dulce, Costa Rica. Revista de Biología Tropical, 54(1): 147-170.

Unión Internacional para la Conservación de la Naturaleza (UICN). 2016. Categorías y criterios de la lista roja de la UICN. Versión 3.1. Colchester Print Group, Norfolk.

Viana, I., Valiela, I., Martinetto, P., Monterio, R. \& Fox, S. 2015. Isotopic studies in Pacific Panama mangrove estuaries reveal a lack of watershed deforestation on food webs. Marine Environmental Research, 103: 95102.

Wallace, B.P., DiMatteo, A., Bolten, A.B., Chaloupka, M.Y., Hutchinson, B.J., Abreu-Grobois, F.A., et al. 2011. Global conversation priorities for marine turtles. Plos One, 6(9): e24510.

Wallace, B.P, DiMatteo, A.D., Hurley, B.J., Finkbeiner, E.M., Bolten, A.B., Chaloupka, M.Y., et al. 2010. Regional management units for marine turtles: a novel framework for prioritizing conservation and research across multiple scales. Plos One, 5(12): e15465.

Ward, T., Vanderklift, A., Nicholls, A. \& Kenchington, R. 1999. Selecting marine reserves using habitats and species assemblages as surrogates for biological diversity. Ecological Applications, 9(2): 691-698.

Williams, N., Bjorndal, K., Lamont, M. \& Carthy, R. 2014. Winter diets of immature green turtles (Chelonia mydas) on a northern feeding ground: integrating stomach contents and stable isotope analyses. Estuaries and Coasts, 37: 986-994.

Wood, L.D., Brunnick, B. \& Milton, S.L. 2017. Home range and movement patterns of subadult hawksbill sea turtles in Southeast Florida. Journal of Herpetology, 51(1): 58-67. 